\title{
Plant species diversity in a Neotropical wetland: patterns of similarity, effects of distance, and altitude
}

\author{
FRANCIELLI BAO ${ }^{1}$, THALES D. LEANDRO ${ }^{1}$, MAÍRA DA ROCHA ${ }^{2}$, VANESSA S. DOS SANTOS ${ }^{3}$, THIAGO \\ H. STEFANELLO ${ }^{4}$, RAFAEL ARRUDA ${ }^{5}$, ARNILDO POTT ${ }^{4}$ and GERALDO A. DAMASCENO-JÚNIOR ${ }^{4}$ \\ ${ }^{1}$ Universidade Estadual Paulista/UNESP, Instituto de Biociências, Departamento de \\ Botânica, Av. 24A, 1515, Bela Vista, 13506-900 Rio Claro, SP, Brazil \\ ${ }^{2}$ Instituto Nacional de Pesquisas da Amazônia/INPA, Laboratório de Botânica, Av. \\ André Araújo, 2936, Aleixo, 69060-001 Manaus, AM, Brazil \\ ${ }^{3}$ Universidade Federal de Mato Grosso do Sul/UFMS, Laboratório de Produtos Naturais e Espectrometria de Massas, Centro \\ de Ciências Biológicas e da Saúde, Av. Costa e Silva, 549, Cidade Universitária, 79070-900 Campo Grande, MS, Brazil \\ ${ }^{4}$ Universidade Federal de Mato Grosso do Sul/UFMS, Instituto de Biociências, Av. Costa \\ e Silva, 549, Cidade Universitária, 79070-900 Campo Grande, MS, Brazil \\ ${ }^{5}$ Universidade Federal de Mato Grosso, Instituto de Ciências Naturais, Humanas e Sociais, \\ Av. Alexandre Ferronato, 1200, Cidade Jardim, 78550-728 Sinop, MT, Brazil
}

Manuscript received on July 1, 2015; accepted for publication on June 29, 2016

\begin{abstract}
The Brazilian Pantanal is an extensive wetland with heterogeneous habitats, primarily due to the riverfloodplain system and plants with differential adaptations and reproductive strategies. Factors such as altitude, distance among plant formations, and flood pulse must be considered to better understand its diversity. Aiming to assess the influence of biogeographic patterns in this system, we analyzed the floristic composition of six areas along the Paraguay River, including residual relieves, verifying the pattern of similarity, and effects of distance and altitude. We recorded 356 species in 87 families, mostly perennial $(75 \%)$, and some annuals $(15 \%)$ and pluriannuals $(5 \%)$. Herbaceous plants were the most represented (48\%), followed by arboreal (23\%), shrubby (15\%) and epiphytic (14\%) habits, only $12 \%$ being endemic to Brazil. The studied areas showed low floristic similarity, but higher resemblance of species between neighboring areas, and no relation with altitude. The upper Paraguay River is diverse, with high spatial variability of species, predominantly perennial. The river-floodplain connectivity may be a determinant factor in species richness and occurrence of endemic species.
\end{abstract}

Key words: biogeography, floodplain, floristics, Pantanal, vegetation.

\section{INTRODUCTION}

Continental wetlands comprise a complex of ecosystems forming a mosaic with high species

Correspondence to: Francielli Bao

E-mail: franbao@yahoo.com.br diversity (Nunes da Cunha and Junk 2001) that increases the spatial variability of their occurrence (Junk et al. 2006). Floods in wetlands may occur in a periodical and irregular hydrological cycle (Nunes da Cunha and Junk 2001), evidencing the traits of many terrestrial (Scarano 1998), amphibious, and 
aquatic plants (Scremin-Dias 2000, Scremin-Dias et al. 2011). These plants represent a diversified set of species with differential adaptations and ecological strategies for maintenance of diversity, allowing them to survive in waterlogged or flooded soils (Kozlowski et al. 1991, Cronk and Fennessy 2001, Cattanio et al. 2002). Different flood tolerances lead to changes in structure and species composition over a geographical gradient (Ferreira and Parolin 2007, Costa et al. 2009, Sanches et al. 2013). Several authors have reported altitude as one of the main factors to influence the pattern of species colonization (e.g., Lieberman et al. 1995, Pendry and Proctor 1996, Oliveira-Filho and Fontes 2000, Eisenlohr et al. 2013); but other combined factors must also be considered such as geographic distance between sites (Diniz-Filho et al. 2012), topography, flood duration (DamascenoJúnior et al. 2005), and the transport of seeds (Harper 1988, Fenner and Thompson 2005). This set of factors directly influences characteristics of each species, such as propagation, reproduction, germination, and competition (Capon and Brock 2006), which may increase the species diversity over short distances (Brock 2011).

Tropical floodplain environments such as the Pantanal are the largest contributors to the global diversity (Myers et al. 2000), since the species abundance, population density, and their distribution usually act increasing and/or reducing the diversity of each environment (Scheiner and Rey-Benayas 1994). The Pantanal is considered one of the main tropical floodplains (Junk et al. 2014), including heterogeneous environments with different influences often from the river-floodplain interaction, but also from the distinct surrounding vegetation types, striking hydric seasonality, and edaphic variations (Alho 2008). Hence, studies on biogeographic patterns are indispensable for understanding the similarity among different plant communities (Pringle 2001) in the Pantanal floodplain and associated residual relieves.
In this context, considering that the upper Paraguay floodplain and residual relieves has been the less studied sub-region of the Pantanal wetland in terms of flora, but also for its importance, our aim was perform a floristic survey in this remote area to evaluate and compare both species composition and richness. We carried out this work in six vegetation formations along the Paraguay River, addressing the following questions: (i) Do areas connected during flood periods differ in floristic similarity? (ii) Is there a pattern of floristic composition associated with altitude? (iii) How floristic similarity can be explained by distance among areas?

\section{MATERIALS AND METHODS}

\section{GENERAL CHARACTERIZATION OF THE STUDY AREAS}

The six studied areas are located in the sub-region named Paraguay, along the Paraguay River in the Brazilian Pantanal (Silva and Abdon 1998). The whole area is located upstream from the town of Corumbá, State of Mato Grosso do Sul, near the border of the State of Mato Grosso, including part of the border stretch of Brazil and Bolivia (Fig. 1).

The climate of the region is classified as "Awa" type, tropical of altitude, megathermal, and with dry winter and rainy summer (Köppen 1948). Temperatures range from close to $0^{\circ} \mathrm{C}$ between May and August and to $40^{\circ} \mathrm{C}$ between November and March. The rainy season is between November and March, with mean annual rainfall of $1,070 \mathrm{~mm}$ and average annual relative air humidity of $76.8 \%$ (Soriano 1997). Moreover, the strong seasonality is characterized by well-defined periods of drought and flood (Carvalho 1986), with highest flood levels in June and July, and lowest levels in December and January (Figure S1 - Supplementary Material). Floods in this area depend on a three months of delayed flow from the headwaters and then cover large floodplain areas along the main riverbed 


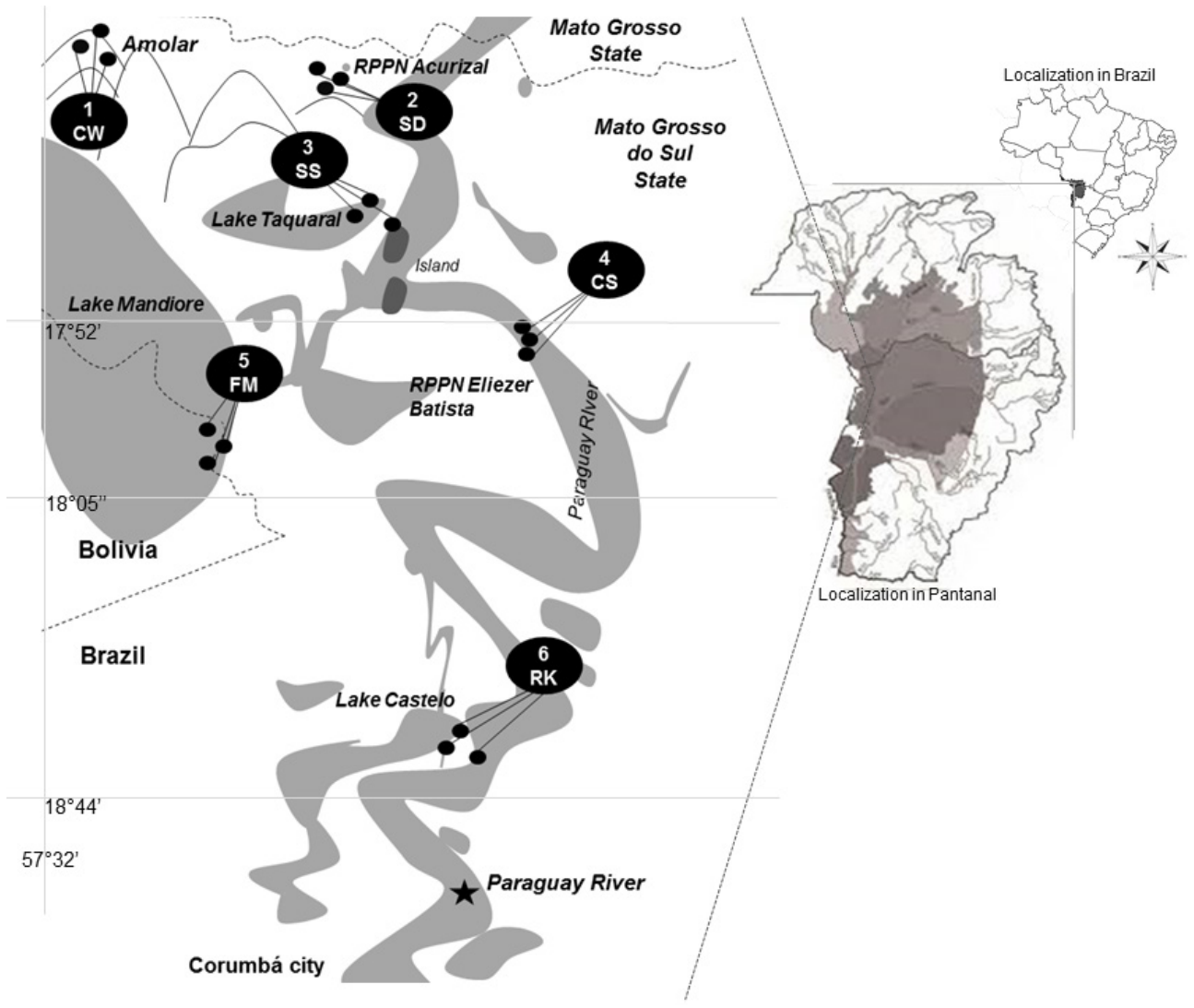

Figure 1 - Spatial distribution of the three collection sites in each studied area in the floodplain and residual relieves of the Upper Paraguay River, Pantanal wetland, Mato Grosso do Sul, Brazil, (map adapted from Silva and Abdon 1998). Area 1: CW (Cerrado woodland under impact of fire) - Serra do Amolar; Area 2: SD (seasonal semideciduous forest) - RPPN (private reserve) Acurizal; Area 3: SS (shrubby swamp with tree islets) - Lake Taquaral; Area 4: CS (Cerrado and semideciduous forest) - RPPN Eliezer Batista; Area 5: FM (floodable meadow) - Lake Mandioré; Area 6: RK (seasonal alluvial forest with rocky outcrop) - Lake Castelo.

(Hamilton et al. 1996). The Paraguay River level is highly variable among seasons, and oscillated between 1 and 4.20 meters in 2010 (Oliveira et al. 2014). Therefore, our collections were made in November 2010, when the river level was close to its minimum, allowing access, otherwise restricted due to flooding.

\section{DATA SAMPLING}

The study was carried out in six areas with different vegetation types, on the floodplain and residual relieves (Table I): Area 1: CW (Cerrado woodland under impact of fire) - Serra do Amolar; Area 2: SD (seasonal semideciduous forest)- RPPN (private reserve) Acurizal; Area 3: SS (shrubby swamp with tree islets) - Lake Taquaral; Area 4: CS (Cerrado and semideciduous forest) - RPPN Eliezer Batista; Area 5: FM (floodable meadow) - Lake Mandioré; Area 6: RK (seasonal alluvial forest with rocky outcrop) - Lake Castelo. To cover a wide range of species diversity, the survey was performed in three collection sites in each area (Fig. 1), considering the three sampled sites as a sampling unit. For correlation among areas they were separated considering the following variables: i. qualitative: vegetation and soil types; ii. quantitative: altitude (m) and geographic coordinates (the later for analysis of distance between areas) (Table I).

Time was utilized as a standard measure of sampling effort. A team comprising five people 
TABLE I

Vegetation types, soil, altitude data and geographic coordinates of the six studied areas along the Paraguay River, Pantanal, Brazil. Area 1: CW - Serra do Amolar; Area 2: SD - RPPN Acurizal; Area 3: SS - Lake Taquaral; Area 4: CS RPPN Eliezer Batista; Area 5: FM - Lake Mandioré; Area 6: RK - Lake Castelo.

\begin{tabular}{|c|c|c|c|c|}
\hline Areas & Vegetation type & Altitude (m) & Soil type & $\begin{array}{l}\text { Geographic coordinates } \\
\text { (lat, long) }\end{array}$ \\
\hline $\mathrm{CW}$ & Cerrado woodland with impact of fire & 645 & sandy-litolic & $18^{\circ} 02^{\prime} 18,60^{\prime \prime} \mathrm{S}, 57^{\circ} 30^{\prime} 55,00^{\prime \prime} \mathrm{W}$ \\
\hline $\mathrm{SD}$ & semideciduous forest & 186 & sandy-litolic & $17^{\circ} 44^{\prime} 18,10^{\prime} \mathrm{S}, 57^{\circ} 41^{\prime} 27,80^{\prime \prime} \mathrm{W}$ \\
\hline SS & Shrubby swamp with islets & 97 & clay-sandy & $18^{\circ} 02^{\prime} 32,40^{\prime \prime} \mathrm{S}, 57^{\circ} 29^{\prime} 27,40^{\prime \prime} \mathrm{W}$ \\
\hline $\mathrm{CS}$ & Cerrado and semideciduous forest & 95 & sandy & $18^{\circ} 05^{\prime} 40,20^{\prime} \mathrm{S}, 57^{\circ} 29^{\prime} 15,30^{\prime \prime} \mathrm{W}$ \\
\hline FM & Floodable meadow & 90 & clay-sandy & $18^{\circ} 55^{\prime} 40,00^{\prime \prime} \mathrm{S}, 57^{\circ} 30^{\prime} 10,50^{\prime \prime} \mathrm{W}$ \\
\hline RK & $\begin{array}{c}\text { Seasonal alluvial forest with rocky } \\
\text { outcrops }\end{array}$ & 88 & sandy & $18^{\circ} 35^{\prime} 26,00^{\prime \prime} \mathrm{S}, 57^{\circ} 32^{\prime} 44,70^{\prime \prime} \mathrm{W}$ \\
\hline
\end{tabular}

spent an average of five hours per point until we observed a stabilization of additional number of species. Species were classified with regard to: i. habit [herbaceous, arboreal, shrubby, liana (climber) or epiphitic]; ii. vegetation type; iii. life cycle (perennial, annual or pluriannual); and iv. origin and endemism (native or exotic, and endemic or non-endemic to Brazil) (following Forzza et al. 2010). Since there is a low number of endemic species in the Pantanal because of its recent geological history (Ab'Saber 1939), and the flora originates itself from surrounding vegetation types (Pott et al. 2011), the information regarding endemisms were considered for Brazil (Pott and Pott 1999, Pott et al. 2011). We determined floristic differences between the studied areas with a dendrogram (Unweighted Pair Group Method UPGMA), using the Jaccard index of community dissimilarity-because the matrix is binary.

Species identification was achieved by comparison with specimens of the Herbarium CGMS of the Universidade Federal de Mato Grosso do Sul (UFMS), plant guides (Pott and Pott 1994, 2000, Lorenzi 2008, Souza and Lorenzi 2008), and assistance from experts. For both fertile and sterile materials, we applied the usual herbarium techniques (Bridson and Forman 1992). Classification for Angisosperm families followed APG IV (2016), Shaw et al. (2011) for Bryophytes, and Kramer and Green (1990) and Smith et al. (2006) for Lycophytes. All collected fertile material was included in Herbarium CGMS (Table SI - Supplementary Material).

\section{DATA ANALYSIS}

To test the hypothesis that altitude drives patterns of the floristic variation, we summarized a matrix of presence/absence data using Principal Coordinates Analysis (PCoA), with Sørensen's distance, which is equivalent to the Bray-Curtis measure in a binary form (presence/absence). The first three axes resulting from ordination were used as dependent variables in a model of Multivariate Analysis of Variance (MANOVA), and the p-value was estimated by Pillai-Trace statistics. In this model, we predicted that variations in species composition are explained by altitude as a quantitative parameter that represents vegetation type characterististics of sampling areas. The composition data were divided by four habits (herbaceous, arboreal, shrubby, and liana (climber or epiphytic)). Plant distribution patterns may be explained by altitude, which can lead to many changes in structure and species composition. Hence, we are predicting that the altitude is influencing variations in the vegetation 
composition. For species richness, we built a twoway ANOVA model, to seek the average difference of richness in altitude between the six sampling areas. In case of significant ANOVA results, we used Tukey's HSD (honest significant difference) test to stablish multiple comparisions.

To test the hypothesis that the floristic patterns are distance-dependent, we set a Generalized Linear Model (GLM) assuming both a Poisson error distribution and a log function. In this model we investigate whether the number of species shared between the sampled areas is explained by the linear distance between them. In order to build the independent variables in this model, we calculated the species richness shared between the studied areas and the linear distance in kilometers. Additionally, we used Mantel test to determine whether the community structure is correlated with distance between the sampled areas (controlling spatial autocorrelation). The Mantel coefficient was calculated by Pearson's product-moment correlation, in which we used 1.000 permutations and 500 interations for the bootstrapped confidence limits. Moreover, we constructed a similarity matrix of geographical coordinates using the Euclidian distance.

All analyses were performed in R environment ( $\mathrm{R}$ core team 2015) using the vegan (Oksanen et al. 2015) and ecodist (Goslee and Urban 2007) packages.

\section{RESULTS}

\section{FLORISTIC PATTERNS}

The floristic survey showed 356 species in 268 genera and 87 families. Angiosperms are the group with the highest number of species, mainly represented by Fabaceae (40 species), followed by Poaceae (26), Cyperaceae and Euphorbiaceae (22 each), Rubiaceae (20), Malvaceae (14), Apocynaceae, Asteraceae and Melastomataceae (ten each), Myrtaceae (eight), Onagraceae (seven), Sapotaceae (six) and Annonaceae, Combretaceae, Crysobalanaceae and Passifloraceae (five species each) (Table SI). These families together represent almost $50 \%$ of the sampled specimens. Cyperus (Cyperaceae) and Ludwigia (Onagraceae) were recorded in all the sampled areas. Lycophytes represent thirteen recorded species and nine families: Pteridaceae (four species), Marsileaceae (two), plus seven other families with a single species each. Bryophytes are represented by a single family, Ricciaceae (Hepatophyta).

Regarding the life cycle, about $75 \%$ are perennial, $15 \%$ annual, and $5 \%$ pluriannual. The herbaceous habit was the most represented (150 species in total), followed by arboreal (83), shrubby (74), and lianas (48). Poaceae, Cyperaceae, Euphorbiaceae, and Asteraceae have the highest representativity within the herbaceous stratum, in which Steinchisma laxum was the most frequent species among different sampled areas. For the arboreal stratum, Fabaceae, Rubiaceae, and Myrtaceae comprise $70 \%$ of richness, with Inga vera recorded in about $50 \%$ of sampled areas.

Only $12 \%$ of sampled species are considered endemic to Brazil. The alluvial forest of Lake Castelo "RK" and the Cerrado "CW" on top of Serra do Amolar had the highest occurrence of endemic species (both with com 28\%), followed by semideciduous forest and Cerrado "CS" of RPPN Eliezer Batista (17\%), and shrubby swamp "SS" of Lake Taquaral (13\%). The seasonal semideciduous forest "SD" (8\%) and the floodable meadow "FM" $(6 \%)$, near to the Bolivian border, showed lower percentage of endemic species (Table SI).

\section{FLORISTIC SIMILARITY IN AREAS CONNECTED BY FLOOD}

The six studied areas showed variation in species richness (Table II) and a great number of herbaceous plants (Table II). The richness data showed a significant mean difference for plant habit (Two- 
way ANOVA: $\mathrm{F}_{3,15}=7.71, \mathrm{p}=0.002$, Fig. 2a). Regarding the richness data per habit, lianas and herbs (Tukey's HSD: $p=0.004$ ) and shrubs and herbs (Tukey's HSD: $p=0.005$ ) were responsible for the significance in the ANOVA model. For herbs and trees, we observed a marginally significant mean difference (Tukey's HSD: $\mathrm{p}=0.09$ ).

We found the highest species richness in "SD", with recorded occurrence for all listed habits including $80 \%$ of families and genera with a single species each (Table II). In this area, we also found a single specimen of Orchidaceae, Vanilla palmarum, and $60 \%$ of the recorded Lycophytes (e.g., Adiantum deflectens, Phlebodium decumanum, Selaginella sellowii and Thelypteris serrata).

The areas "SS" and "RK" (with 79 and 74 species, respectively) exhibited mainly herbaceous species, mostly Fabaceae and Euphorbiaceae (Table II). The "SS" area also exhibited the highest occurrence of aquatic plants (macrophytes), such as Ludwigia (three species), Cyperus (four), Eleocharis (two), and Victoria amazonica. In contrast, in "RK" we found the only two recorded species of Cactaceae, Pereskia sacharosa and Praecereus euchlorus.

The areas with lowest species richness were "CW" (14\%), followed by "FM" (10\%), and "CS" $(8 \%)$. The Cerrado area under influence of fire ("CW") exhibited a low number of herbaceous species, whereas it showed great richness of trees, shrubs and lianas. The "FM" area exhibited predominance of Cyperaceae, mainly species of Cyperus. Although "CS" showed the lowest species richness, there we recorded the only species of Bromeliaceae, the small epiphyte Tillandsia loliacea.

In general, a low species similarity occurred among the sampled areas, even with the connection of areas by the Paraguay River (Fig. 3). However, we were able to observe three groups: i. "SS" + "SD" - with highest species similarity (17 species); ii. "CS" + "CW" (seven); and iii. "FM" + "RK" (five), which in turn showed the lowest relation between areas.
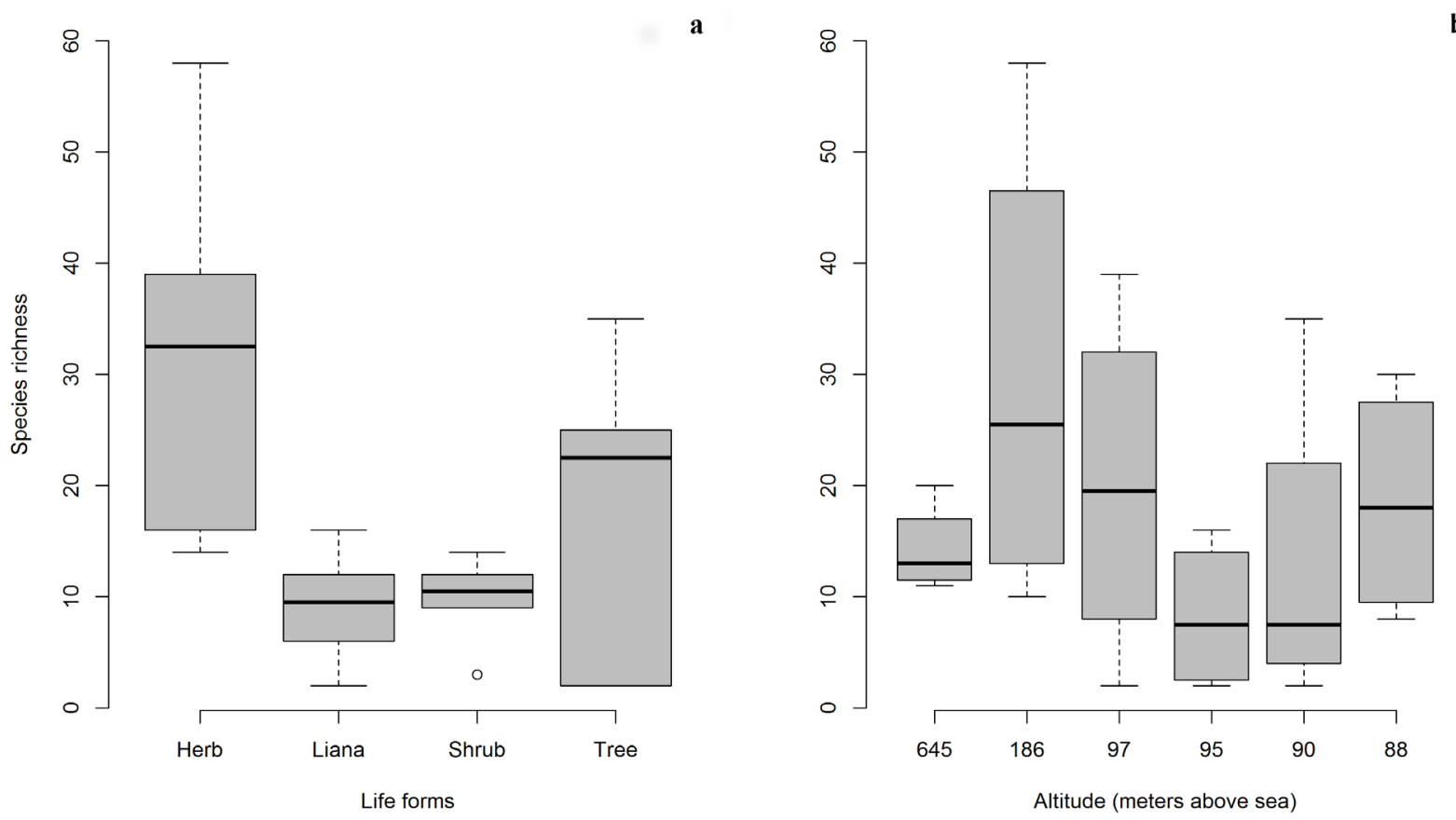

Figure 2 - Comparison of species richness in the sampled areas along the Paraguay River, Pantanal, Brazil. a - species richness per growth habit; $\mathbf{b}$ - species richness for each sampled environment (number of areas is available in Table I). 
TABLE II

Richness of species, families and genera, and number of species per habit in the six studied areas along the Paraguay River, Pantanal, Brazil.

\begin{tabular}{cccccccc}
\hline Area & $\begin{array}{c}\text { Species } \\
\text { richness }\end{array}$ & $\begin{array}{c}\text { Family } \\
\text { richness }\end{array}$ & $\begin{array}{c}\text { Genus } \\
\text { richness }\end{array}$ & $\begin{array}{c}\text { Number of } \\
\text { herbs }\end{array}$ & $\begin{array}{c}\text { Number of } \\
\text { trees }\end{array}$ & $\begin{array}{c}\text { Number of } \\
\text { shrubs }\end{array}$ & $\begin{array}{c}\text { Number of epiphytes, lianas } \\
\text { (climber or epiphytic) }\end{array}$ \\
\hline CW & 49 & 29 & 58 & 10 & 14 & 18 & 11 \\
SD & 100 & 37 & 100 & 46 & 25 & 21 & 10 \\
SS & 70 & 26 & 64 & 34 & 20 & 11 & 5 \\
CS & 29 & 14 & 43 & 11 & 2 & 6 & 6 \\
FM & 47 & 21 & 52 & 33 & 2 & 6 & 6 \\
RK & 60 & 21 & 64 & 22 & 20 & 12 & 6 \\
\hline
\end{tabular}

The "SS" + "SD" areas showed a higher similarity due to the short distance between them. The increased similarity between these areas was higher because of the herbs, mostly Eleocharis minima and Steinchisma laxum. However, for the cluster "CS" + "CW" the similarity was maintained by the high number of trees and lianas, mainly Fabaceae.

Vegetation characteristics common to "FM" + "RK" did not contribute to increase their similarity, since the distance between them reduced it. In this cluster only Eichhornia crassipes exhibited high

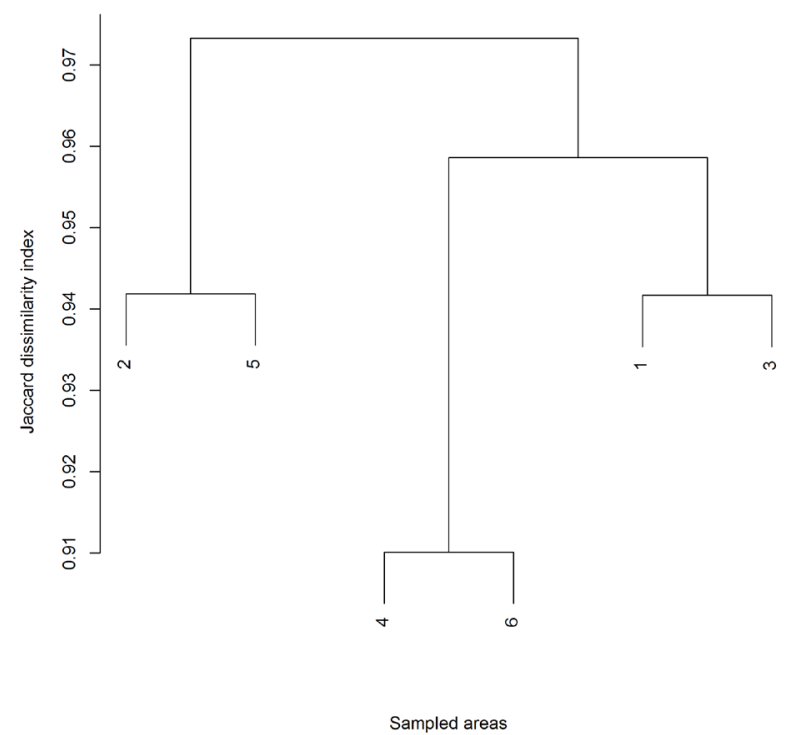

Figure 3 - Cluster (UPGMA) of species by similarity (Jaccard index) among the six sampled areas along the Paraguay River, Pantanal wetland, Brazil (number of areas are available in Table I). occurrence, but the richness of both Cyperaceae and Poaceae in "FM" area contributed to decrease the similarity.

\section{ALTITUDE PATTERNS OF FLORISTIC VARIATION}

The first three axes from the PCoA ordination generated $23 \%$ of the original variation, and we also observed that variation in species composition (MANOVA: Pillai-Trace $=0.69, \mathrm{p}=0.42$ ) was not explained by altitude, but had marginally significant mean difference for richness (Two-way ANOVA: $\mathrm{F}_{5,15}=2.49, \mathrm{p}=0.08$, Fig. 2b).

\section{DISTANCE EFFECTS OF FLORISTIC VARIATION}

Mantel values showed that the community did not exhibit a significative spatial dependence (Mantel: $\left.\mathrm{r}_{\mathrm{m}}=0.12, \mathrm{p}=0.31\right)$. Therefore, we were able to infer that no spatial auto-correlation exists between the sampled areas. Finally, the variation in number of shared species was not explained by linear distance between the studied areas (Poisson GLM: $\left.\chi^{2}=27.41, \mathrm{p}=0.95\right)$.

\section{DISCUSSION}

\section{FLORISTIC PATTERNS}

In this work, we observed the floristic diversity and the differences in vegetation composition between the sampled areas, which contributes to the heterogeneity found in the Brazilian Pantanal 
previously reported by other authors (e.g., Alho 2008). All Angiosperms herein recorded are included in the Pantanal plant list (Pott and Pott 1999), and also all Angiosperms, Bryophytes, and Lycophytes in the Brazilian Flora List (Forzza et al. 2010).

Our inventory reveals some endemic species to Brazil that compose the flora of the Pantanal, such as Eragrostis hypnoides (Poaceae). Other phytogeographic influences, such as Amazonia from the North and Cerrado from the East (Adámoli 1982), contribute to the low number of endemic species in the Pantanal. Furthermore, the interaction river-floodplain during the floods (Bornette et al. 1998) plus the recent geological history of the region (Ab'Saber 1939, Pott et al. 2011) are determinant factors that also contribute reducing the richness and occurrence of endemic species (Bornette et al. 1998).

Many of the largest Angiosperm families in Brazil (Fabaceae, Asteraceae, Euphorbiaceae, and Myrtaceae) have a strong endemism (Giulietti et al. 2005), but in the Pantanal they are just widespread among the vegetation types. In this case, the riverfloodplain interaction may increase the species richness (Bornette et al. 1998). Our inventory also reported a high diversity of native plants, mainly within Fabaceae and Cyperaceae. The genus Cyperus is the most representative within Cyperaceae, with some species widely spread in the Pantanal (e.g., Cyperus haspan, C. odoratus, and $C$. surinamensis) (Pott and Pott 2000). The great number of native species of Fabaceae and Cyperaceae in the Pantanal was also reported in other studies (Pott et al. 2011, Amador et al. 2012, Catian et al. 2012, Rocha et al. 2015).

With regard to the both permanent and seasonal flooded environments, the presence of Alismataceae, Marsileaceae, Pontederiaceae, Ricciaceae, and Salviniaceae increased the diversity of aquatic macrophytes. The high diversity of aquatic plants is a consequence of their different life forms (Irgang et al. 1996), which allow them to grow in different habitats and hydric conditions (Scremin-Dias 2000), as observed in Ludwigia.

\section{ALTITUDE, SPECIES RICHNESS AND PLANT ADAPTATIONS}

The floristic composition among the sampled areas did not follow the altitudinal gradient, as species richness would be expected to decrease with increased altitude (Von Humboldt and Bonpland 1807, Brown and Gibson 1983, Givnish 1999). This suggests that the main shaping source of this community is the seasonal flood promoting some homogenization of different areas. The Pantanal wetlands comprise a high variation in species composition due to the different regimes of flood pulse by function of the altitudinal gradient (Junk et al. 1989), and both drought and flood periods may stimulate or inhibit seed germination (Casanova and Brock 2000) and seedling establishment (Simpson et al. 1989). The variation in flood pulse over the years may spread many seeds, thus increasing the chances of species establishment. Furthermore, periodical flood events promote an increase in the dispersal process, influencing the species distribution along a gradient. Hence, species richness varies over different gradient levels in response to the flood pulse within a spatial-temporal scale.

The variation in species richness between the sampled areas indicates that the particular adaptation traits are fundamental factors in the colonization of each environment. The Pantanal contains a high floristic diversity (Nunes da Cunha and Junk 2001), and the vegetation types are characterized by many plants assumed as indicators species; for the plants herein recorded, we can mention: Qualea grandiflora, widely distributed in the Cerrado (Ratter et al. 1996); Curatella americana, indicator of savanna; and Xylopia aromatica, indicator of semideciduous forest (Felfili et al. 2002), which supports the influence of the surrounding vegetation 
types on the floristic composition of the Pantanal (Adámoli 1982).

Ricciocarpos natans populations (Bryophyte) are common in flooded habitats in the Pantanal, mostly due to morphological and functional adaptations to survive under hydric stress. In contrast, the Lycophytes herein recorded are typical of seasonal forests (Smith et al. 1999), but nonendemic, although Brazil is considered one of the main centers of endemism and speciation of this group (Tryon 1986).

The low species diversity and the lower herbaceous ground cover observed in " $\mathrm{CW}$ " (Cerrado woodland under impact of fire) may be result of wildfire on top of the hill. This disturbance reduces the ground cover of herbaceous species and stimulates the production of buds and regrowth of shrubby species (Fidelis et al. 2014). On the other hand, the great ground cover of trees found in "CW" is probably due to their strategies against fire, such as growth in height and bark thickness (Dantas and Pausas 2013)-typical features of Cerrado woody species. Furthermore, altitude in this area may select species that are not flooddispersed or areas that receive less incoming seeds during flood (Baldwin et al. 2010). Hence, the main dispersal vectors plus the flood events provide a further gain in species diversity in this region.

In general, some responses to the environmental factors were observed among the recorded species, such as: i. morphological structures and functional adaptations that provide the colonization by aquatic plants (Casanova and Brock 2000); ii. propagation strategies, such as bank of buds arising from the aerial and underground organs (Fidelis et al. 2014); and iii. reproductive strategies, such as dispersal and the soil seed bank by function of an altitudinal gradient (Baldwin et al. 2010). Seed dispersal, as well as germination and colonization of these species by function of a flood regime may evidence particular both morphological and physiological traits in response to environmental conditions.
Considering the great number of floodable areas in the Pantanal (Pott and Pott 1999), we support that the predominance of herbaceous species in this region is due to their capability to establish under conditions of water stress (e.g., Scremin-Dias 2000, Leandro et al. 2016).

\section{SIMILARITY AND DISTANCE EFFECTS}

The most similar areas were grouped according to the characteristics of each vegetation type, which may be explained by their proximity. In these types of areas, diversity is usually higher and species composition may vary in short distances (Scheiner and Rey-Benayas 1994, RodriguesIturbe et al. 2009), whereas large distances may decrease similarity for several reasons, such as variations in the gradient and differences in niche occupation and dispersal limitation (Necola and White 1999, Boedeltje et al. 2003, Nilsson et al. 2010). These variations may influence the pattern of species colonization, mainly due to dispersal strategies such as hydrochory (Barrat-Segretain 1996, Wittmann and Junk 2003, Riis and SandJensen 2006, Hopfensperger and Baldwin 2009). Although the sampled areas are connected by the Paraguay River, the distance between them acts as a determinant factor, which increases and/or decreases the similarity between different formations (Gurnell et al. 2006, Thomaz et al. 2009).

In the Pantanal, seed transportation may be restricted to short distances due to natural barriers caused by the geomorphological complexity (Fantin-Cruz et al. 2011, Pagotto et al. 2011). Species richness and abundance increase due to different capabilities of seed retention (Bao et al. 2014), and also by the physiological limitation of seeds by function of the submersal period (Brock 2011). Therefore, the difference in species composition of these environments may be explained by the Paraguay River flood pulse, 
which directly influences the seed bank build-up (Baker 1989, Damasceno-Júnior et al. 2005). The river-plain interaction in flooding periods has been considered important to explain the similarities of differentes groups of aquatic organisms (Ward and Tockner 2001). Understanding these similarities may explain the patterns of species richness and rarity in wetlands, which allows to predict the community dynamics and to develop guidelines for biodiversity conservation (Bornette et al. 1998).

Since germination usually is influenced by factors such as dormancy, viability, physiology, temperature, light, and nutrients (Baker 1989, Dupin et al. 2009, Baskin and Baskin 2014), occasionally, seed arrival does not assure the species establishment. The variation in species richness within a community comprising species with diverse strategies of regeneration and maintenance can be influenced by a high percentage of perennial species (Callaway 1995). In this case, the community includes mainly grasses with stoloniferous rhizomes (Bonnis et al. 1995), along with some species with low propagation rates and restricted to a single area (Brock 2011). Equally, some environmental conditions shall be taken into account for reducing species similarity between environments-evidencing the high differential index in the floristic composition between distant areas.

Herein we report that there is no evidence of floristic variation influenced by altitude, however, the flood pulse and spatial proximity in the Pantanal is crucial to the structure of plant community. Our results suggest that the upper Paraguay floodplain includes a wide range of diversity along the river. Since the high richness herein highlighted indicates that these remote areas should be better studied to strengthen efforts concerning the biological heritage and definition of priority areas for biodiversity conservation, it is important to further investigate the processes that generate and maintain species composition and diversity.

\section{ACKNOWLEDGMENTS}

The authors are grateful to the Brazilian agencies Conselho Nacional de Desenvolvimento Científico e Tecnológico (CNPq), Coordenação de Aperfeiçoamento de Pessoal de Nível Superior (CAPES), and Instituto Nacional de Ciência e Tecnologia em Áreas Úmidas (INAU) for financial support, scholarships (F. Bao; T.D. Leandro PNADB/CAPES process number 308793/2013-7), research grants (A. Pott) and G.A. DamascenoJúnior to Universidade Federal de Mato Grosso do Sul for logistical support; and Vali J. Pott for her assistence with species identification.

\section{REFERENCES}

AB'SABER AN. 1939. O Pantanal Mato-grossense e a Teoria dos Refúgios. Rev Bras Geo 1: 9-57.

ADÁMOLI J. 1982. O Pantanal e suas relações fitogeográficas com os Cerrados: discussão sobre o conceito de "Complexo do Pantanal". An Cong Nac Bot 32: 109-119.

ALHO CJR. 2008. Biodiversity of the Pantanal: response to seasonal flooding regime and to environmental degradation. Braz J Biol 68: 957-966.

AMADOR GA, DAMASCENO-JÚNIOR GA, CASAGRANDE JC AND SARTORI ALB. 2012. Structure of two communities dominated by Copernicia $a l b a$ and associations with soil and inundation in Pantanal wetland, Brazil. Oecol Australis 16: 846-858.

APG IV. 2016. An update of the Angiosperm Phylogeny Group classification for the orders and families of flowering plants: APG IV. Bot J Linean Soc 181: 1-20.

BAKER HG. 1989. Some aspects of the natural hystory of seed banks. In: Leck MA, Parker VT and Simpson RL (Eds), Ecology of soil seed banks, Academic Press, London, p. 5-19.

BALDWIN AH, KETTENRING KM AND WHIGHAM DF. 2010. Seed banks of Phragmites australis-dominated brackish wetlands: Relationships to seed viability, inundation, and land cover. Aquatic Bot 93: 163-169.

BAO F, POTT A, FERREIRA FA AND ARRUDA R. 2014. Soil seed bank of floodable native and cultivated grassland in the Pantanal wetland: effects of flood gradient, season and species invasion. Braz J Bot 37: 239-250.

BARRAT-SEGRETAIN MH. 1996. Germination and colonisation dynamics of Nuphar lutea (L.) Sm. in a former river channel. Aquatic Bot 55: 31-38.

BASKIN CC AND BASKIN JM. 2014. Seeds: Ecology, Biogeography, and Evolution of Dormancy and 
Germination, $2^{\text {nd }}$ ed., Academic Press, San Diego, CA, p. 1600.

BOEDELTJE G, BAKKER JP, BEKKER RM, VAN GROENENDAEL JM AND SOESBERGEN M. 2003. Plant dispersal in a lowland stream in relation to occurrence and three specific life-history traits of the species in the species pool. J Ecol 91: 855-866.

BONNIS A, LEPART J AND WHIGHAM DF. 1995. Seed bank dynamics and coexistence of annual macrophytes in a temporary and variable habitat. Oikos 74: 81-92.

BORNETTE G, AMOROS C AND LAMOROUX N. 1998. Aquatic plant diversity in riverine wetlands: the role of connectivity. Freshwater Biol 39: 267-283.

BRIDSON D AND FORMAN L. 1992. The Herbarium Handbook, Royal Botanic Gardens, Richmond, VA, 346 p.

BROCK MA. 2011. Persistence of seed banks in Australian temporary wetlands. Freshwater Biol 56: 1312-1327.

BROWN JH AND GIBSON AC. 1983. Biogeography. Mosby Company, St. Louis, 643 p.

CALLAWAY RM. 1995. Positive interactions among plants. Bot Rev 61: 306-318.

CAPON SJ AND BROCK MA. 2006. Flooding, soil seed bank dynamics and vegetation resilience of a hydrologically variable desert floodplain. Freshwater Biol 51: 206-223.

CARVALHO NO. 1986. Hidrologia da bacia do alto Paraguai. In: Anais do Simpósio sobre Recursos Naturais e Sócioeconômicos do Pantanal, Embrapa, Brasília, p. 43-50.

CASANOVA MT AND BROCK MA. 2000. How do depth, duration and frequency of flooding influence the establishment of wetland plant communities? Plant Ecol 147: 237-250.

CATIAN G, LEME FM, FRANCENER A, CARVALHO FS, GALLETTI VS, POTT A, POTT V, SCREMIN-DIAS E AND DAMASCENO-JÚNIOR GA. 2012. Macrophyte structure in lotic-lentic habitats from Brazilian Pantanal. Oecol Australis 16: 782-796.

CATTANIO JH, ANDERSON AB AND CARVALHO MS. 2002. Floristic composition and topographic variation in a tidal floodplain forest in the Amazon Estuary. Braz J Bot 25: 419-430.

COSTA FRC, GUILLAUMET JL, LIMA AP AND PEREIRA OS. 2009. Gradients within gradients: The mesoscale distribution patterns of palms in a central Amazonian forest. J Veg Sci 20: 69-78.

CRONK JK AND FENNESSY MS. 2001. Wetland Plants: Biology and Ecology, Lewis Publishers, Boca Raton, Fla, $384 \mathrm{p}$.

DAMASCENO-JÚNIOR GA, POTT A, POTT V AND SILVA JSV. 2009. Florestas estacionais no Pantanal, considerações florísticas e subsídios para conservação. Anais $2^{\circ}$ Simpósio de Geotecnologias no Pantanal, Embrapa, Corumbá, p. 784-795.

DAMASCENO-JÚNIOR GA, SEMIR J, SANTOS FAM AND LEITÃO-FILHO HF. 2005. Structure, distribution of species and inundation in a riparian forest of Rio Paraguai, Pantanal, Brazil. Flora 200: 119-135.

DANTAS VL AND PAUSAS JG. 2013. The lanky and the corky: fire-escape strategies in savanna woody species. J Ecol 101: 1265-1272.

DINIZ-FILHO JAF, SIQUEIRA T, PADIAL AA, RANGEL TF, LANDEIRO VL AND BINI LM. 2012. Spatial autocorrelation analysis allows disentangling the balance between neutral and niche processes in metacommunities. Oikos 121: 201-210.

DREBER N AND ESLER KJ. 2011. Spatio-temporal variation in soil seed banks under contrasting grazing regimes following low and high seasonal rainfall in arid Namibia. J Arid Environ 75: 174-184.

DUPIN B, DE ROUWN A, PHANTAHVONG KB AND VALENTIN C. 2009. Assessment of tillage erosion rates on steep slopes in northern Laos. Soil Till Res 103: 119126.

EISENLOHR PV ET AL. 2013. Disturbances, elevation, topography and spatial proximity drive vegetation patterns along an altitudinal gradient of a top biodiversity hotspot. Biodivers Conserv 22: 2767-2783.

FANTIN-CRUZ I, PEDROLLO O, CASTRO NMR, GIRARD P, ZEILHOFER P AND HAMILTON SK. 2011. Historical reconstruction of floodplain inundation in the Pantanal (Brazil) using neural networks. J Hydrol 399: 376-384.

FELFILI JM, NOGUEIRA PE, SILVA JÚNIOR MC, MARIMON BS AND DELITTI WBC. 2002. Composição florística e fitossociologia do Cerrado sentido restrito no município de Água Boa, MT. Acta Bot Bras 16: 103-112.

FENNER M AND THOMPSON K. 2005. The ecology of seeds. Cambridge University Press, Cambridge, 260 p.

FERREIRA LV AND PAROLIN P. 2007. Tree phenology in Central Amazonian floodplain forest: effects of water level fluctuation and precipitation at community and population level. Pesq Bot 58: 139-156.

FIDELIS A, APPEZZATO-DA-GLÓRIA B, PILLAR VD AND PFANDENHAUER J. 2014. Does disturbance affect bud bank size and belowground structures diversity in Brazilian subtropical grasslands? Flora 209: 110-116.

FORZZA RC ET AL. 2010. Introdução. In: Lista de Espécies da Flora do Brasil. Jardim Botânico do Rio de Janeiro, Rio de Janeiro, RJ. Disponível em: http://floradobrasil. jbrj.gov.br/2013.

GIULIETTI AM, HARLEY RM, QUEIROZ LP, WANDERLEY MG AND VAN DEN BERG C. 2005. Biodiversidade e conservação das plantas no Brasil. Megadiversidade 1: 52-61.

GIVNISH TJ. 1999. On the causes of gradient in tropical tree diversity. J Ecol 87: 193-210.

GOSLEE SC AND URBAN DL. 2007. The ecodist package for dissimilarity-based analysis of ecological data. J Statistical Software 22: 1-19. 
GURNELL AM, BOITSIDIS AJ, THOMPSON K AND CLIFFORD NJ. 2006. Seed bank, seed dispersal and vegetation cover: colonization along a newly-created river channel. J Veg Sci 17: 665-674.

HAMILTON SK, SIPPEL SJ AND MELACK JM. 1996. Inundation patterns in the Pantanal wetland of South America determined from passive-microwave remote sensing. Arch Hydrobiol 137: 1-23.

HARPER JL. 1988. An apophasis of plants population biology. In: Symposium of the British Ecological Society 28: 435452.

HOPFENSPERGER KN AND BALDWIN AH. 2009. Spatial and temporal dynamics of floating and drift-line seeds at a tidal freshwater marsh on the Potomac River, USA. Plant Ecol 201: 677-686.

IRGANG BE AND GASTAL JR CVS. 1996. Macrófitas Aquáticas da planície costeira do RS. CPG - Botânica/ UFRGS, Porto Alegre, $120 \mathrm{p}$.

JUNK WJ, BAYLEY PB AND SPARKS RE. 1989. The flood pulse concept in river-floodplain systems. Can Spec Publ Fish Aquatic Sci 106: 110-127.

JUNK WJ, DA CUNHA CN, WANTZEN KM, PETERMANN P, STRUSSMANN C, MARQUES MI AND ADIS J. 2006. Biodiversity and its conservation in the Pantanal of Mato Grosso, Brazil. Aquatic Sci 68: 278-309.

JUNK WJ ET AL. 2014. Brazilian wetlands: their definition, delineation, and classification for research, sustainable management, and protection. Aquatic Conserv: Marine and Freshwater Ecosystems 24: 5-22.

KÖPPEN W. 1948. Climatologia: con un estudio de los climas de la tierra. Fondo de Cultura Económica, México, DF, $478 \mathrm{p}$.

KOZLOWSKI TT, KRAMER PJ AND PALLARDY SG. 1991. The physiological ecology of woody plants. Academic Press, San Diego, CA, 345 p.

KRAMER KUAND GREEN PS. 1990. The families and genera of vascular plants, Pteridophytes and Gymnosperms, $1^{\text {st }}$ ed., Springer Verlag, New York, NY, 410 p.

LEANDRO TD, SCREMIN-DIAS E AND ARRUDA RCO. 2016. Micromorphology and anatomy of the leaf blade: a contribution to the taxonomy of Luziola (Poaceae, Oryzoideae) from the Pantanal, Brazil. P1 Syst Evol 302: 265-273.

LIEBERMAN M, LIEBERMAN D, PERALTA R AND HARTSHORN GS. 1995. Canopy closure and distribution of tropical forest tree species at La selva, Costa Rica. J Trop Ecol 11: 161-178.

LORENZI H. 2008. Árvores brasileiras: manual de identificação e cultivo de plantas arbóreas nativas do Brasil, $5^{\text {a }}$ ed., Instituto Plantarum, Nova Odessa, SP, 368 p.

MYERS N, MITTERMEIER RA, MITTERMEIER CG, FONSECA GAB AND KENT J. 2000. Biodiversity hotspots for conservation priorities. Nature 403: 853-858.
NECOLA JC AND WHITE PS. 1999. The distance decay of similarity in biogeography and ecology. J Biogeog 26: 867-878.

NILSSON C, BROWN RL, JANSSON R AND MERRITT DM. 2010. The role of hydrochory in structuring riparian and wetland vegetation. Biol Rev 85: 837-858.

NUNES DA CUNHA C AND JUNK WJ. 2001. Distribution of woody plant communities along the flood gradient in the Pantanal of Poconé, Mato Grosso, Brazil. Int J Ecol Env Sci 27: 63-70.

OKSANEN J, BLANCHET FG, KINDT R, LEGENDRE P, MINCHIN PR, O'HARA RB, SIMPSON GL, SOLYMOS P, STEVENS MHH AND WAGNER H. 2015. Vegan: Community Ecology Package. R package version 2.3-2. http://CRAN.R-project.org/package=vegan.

OLIVEIRA-FILHO AT AND FONTES MAL. 2000. Patterns of floristic differentiation among Atlantic forests in southeastern Brazil, and the influence of climate. Biotropica 32: 793-810.

OLIVEIRA MT, DAMASCENO-JÚNIOR GA, POTT A, PARANHOS FILHO AC, SUAREZ YR AND PAROLIN P. 2014. Regeneration of riparian forests of the Brazilian Pantanal under flood and fire influence. Forest Ecol Manag 331: 256-263.

PAGOTTO MA, SILVEIRA RML, NUNES DA CUNHA C AND FANTIN-CRUZ I. 2011. Distribution of herbaceous species in the soil seed bank of a flood seasonality area, Northern Pantanal, Brazil. Int Rev Hydrobiol 96: 149-163.

PENDRY CA AND PROCTOR J. 1996. The causes of altitudinal zonation of rain forests on Bukit Belalong, Brunei. J Ecol 84: 407-418.

POTT A AND POTT VJ. 1994. Plantas do Pantanal. Corumbá, Embrapa-CPAP.

POTT A AND POTT VJ. 1999. Flora do Pantanal-Listagem atual de fanerógamas. In: II Simpósio sobre Recursos Naturais e Sócio-Econômicos do Pantanal, Manejo e Conservação, Embrapa Pantanal, Corumbá, MS, p. 298325.

POTT VJ AND POTT A. 2000. Plantas aquáticas do Pantanal. Embrapa, Brasília, 404 p.

POTT VJ, POTT A, LIMA LCP, MOREIRA SN AND OLIVEIRA AKM. 2011. Aquatic macrophyte diversity of the Pantanal wetland and upper basin. Braz J Biol 71: 255263.

PRINGLE C. 2001. Hydrologic connectivity and the management of biological reserves: A global perspective. Ecol Applicat 11: 981-998.

R CORE TEAM. 2015. R: A language and environment for statistical computing. R Foundation for Statistical Computing, Vienna, Austria. URL https://www.R-project. org/.

RATTER JA, BRIDGEWATER S, ATKINSON R AND RIBEIRO JF. 1996. Analysis of the floristic composition 
of the Brazilian Cerrado vegetation II: comparison of the woody vegetation of 98 areas. Edinburgh J Bot 53: 153180.

RIIS T AND SAND-JENSEN K. 2006. Dispersal of plant fragments in small streams. Freshwater Biol 51: 274-286.

ROCHA M, SANTOS-JUNIOR CC, DAMASCENO-JÚNIOR GA, POTT A AND POTT VJ. 2015. Effect of fire on a monodominant floating mat of Cyperus giganteus Vahl in a Neotropical wetland. Braz J Biol 75: 114-124.

RODRIGUES-ITURBE I, MUNEEPEERAKUL R, BERTUZZO E, LEVIN AS AND RINALDO A. 2009. River networks as ecological corridors: a complex systems perspective for integrating hydrologic, geomorphologic, and ecologic dynamics. Water Resour Res 35: 3709-3722.

SANCHEZ M, PEDRONI F, EISENLOHR PV AND OLIVEIRA-FILHO AT. 2013. Changes in tree community composition and structure of Atlantic rain forest on a slope of the Serra do Mar range, Southeastern Brazil, from near sea level to $1000 \mathrm{~m}$ of altitude. Flora 208: 184-196.

SCARANO FRA. 1998. Comparison of dispersal, germination and establishment of woody plants subjected to distinct flooding regimes in Brazilian flood-prone forests and estuarine vegetation. In: Scarano FRA and Franco AC (Eds), Ecophysiological strategies of xerophytic and amphibious plants in the Neotropics. Series Oecologia Brasiliensis v. IV. Rio de Janeiro, Brazil: PPGE-UFRJ, p. 177-193.

SCHEINER SM AND REY-BENAYAS R. 1994. Global patterns of plant diversity. Evol Ecol 8: 331-347.

SCREMIN-DIAS E. 2000. A plasticidade fenotípica das macrófitas aquáticas em resposta à dinâmica sazonal. In: Cavalcati TB and Walter BMT (Eds), Tópicos Atuais em Botânica - Palestras convidadas do $51^{\circ}$ Congresso Nacional de Botânica, Brasília, DF, 400 p.

SCREMIN-DIAS E, LORENZ-LEMKE AP AND OLIVEIRA AKM. 2011. The floristic heterogeneity of Pantanal and the occurrence of species with different strategies to water stress. Braz J Biol 71: 275-282.

SHAW AJ, SZOVÉNYI P AND SHAW B. 2011. Bryophyte diversity and evolution: Windows into the early evolution of land plants. Am J Bot 98: 352-369.

SILVA JSV AND ABDON MM. 1998. Delimitação do Pantanal Brasileiro e suas sub-regiões. Pesq Agrop Bras 33: 1703-1711.

SIMPSON RL, LECK MA AND PARKER VT. 1989. Seed banks: General concepts and methodological issues. In:
Leck MA, Parker VT and Simpson RL (Eds), Ecology of soil seed banks, Academic Press, London, p. 3-8.

SMITH AR, KESSLER M AND GONZALES J. 1999. New Records of Pteridophytes from Bolivia. Am Fern J 89: 244-266.

SMITH AR, PRYER KM, SCHUETTPELZ E, KORALL P, SCHNEIDER H AND WOLF PG. 2006. A classification for extant ferns. Taxon 55: 705-731.

SORIANO BMA. 1997. Caracterização climática de CorumbáMS. EMBRAPA CPAP, Corumbá, MS, 25 p.

SOUZA VC AND LORENZI H. 2008. Botânica sistemática: guia ilustrado para identificação das famílias de fanerógamas nativas e exóticas no Brasil, baseado em APG II, $2^{\mathrm{a}}$ ed., Instituto Plantarum, Nova Odessa, SP, 640 p.

THOMAZ SM, CARVALHO P, PADIAL AA AND KOBAYASHI JT. 2009. Temporal and spatial of aquatic macrophyte diversity in the Upper Paraná River floodplain. Braz J Biol 69: 617-625.

TRYON RM. 1986. The biogeography of species with special reference to ferns. Bot Rev 52: 117-155.

VON HUMBOLDT AA AND BONPLAND A. 1807. Essay on the geography of plants with a physical tableau of the equinoctial regions. Fr. Schoell, Paris. In: Jackson ST (Ed), 2009. Von Humboldt AA. Essay on the geography of plants. University of Chicago Press, Chicago, Illinois, USA, p. 57-143.

WARD J AND TOCKNER K. 2001. Biodiversity: towards a unifying theme for river ecology. Freshwater Biol 46: 807-819.

WITTMANN F AND JUNK WJ. 2003. Sapling communities in Amazonian white-water forests. J Biogeog 30: 15331544.

\section{SUPPLEMENTARY MATERIAL}

Figure S1 - Maximum and minimum water levels of the Paraguay River in centimeters $(\mathrm{cm})$ at Ladário, Pantanal wetland, from 2000 to 2015. Data provided by the National Institute of Meteorology (INMET-BDMEP). The dashed line shows the level of the Paraguay River in 2010 indicating a low-level inundation when the collections were carried out. 